\title{
TYR Gene
}

National Cancer Institute

\section{Source}

National Cancer Institute. TYR Gene. NCI Thesaurus. Code C39670.

This gene is involved in sensory transduction and the biosynthesis of melanin. 